\title{
東北地域における磁界による落雷位置標定システム の高性能化
}

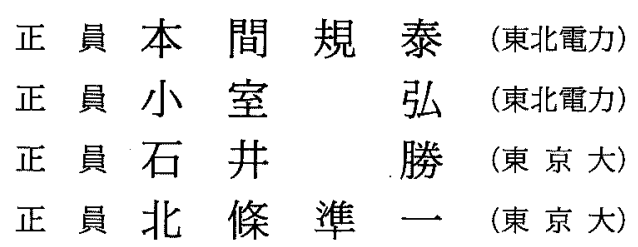

Improvement of a Magnetic Direction-Finder Network in the Tohoku District Noriyasu Honma, Member, Hiroshi Komuro, Member (Tohoku Electric Power Company), Masaru Ishii, Member, Jun-Ichi Hojo, Member (University of Tokyo)

Tohoku Electric Power Company constructed an LLP-system that covered Tohoku District with 9 magnetic direction finders (DFs). This system is capable of locating flashes with current exceeding $10 \mathrm{kA}$ in good location accuracy, throughout the coverage area. The successful operation of this new system was achieved through the modification of waveform discrimination criteria to improve detection efficiency, and through the optimum arrangement of the DFs, together with the evaluation of site error at each DF.

Based on the analysis of the data obtained so far, operational characteristics of the system and some factors which affect the performance of the system have been revealed.

キーワード：LLP システム，サイトエラー，標定精度，最適化標定

\section{1.はじめに}

近年, 日本海沿岸地域の冬季雷研究が精力的に行われて おり，その発生状況の把握などに威力を発揮しているのが 落雷位置標定システムである。現在，電力会社などを中心 に数種類多数のシステムが国内に導入されているが，著者 らは東北地域の雷性状解明を目的として LLP システム(1) を, 昭和 61 年に新潟, 昭和 62 年に秋田に設置して観測を 行ってきた。

LLP システムは，落雷の㷌還雷撃から放射される電磁 波を広帯域で受信し，その到来方位を測定する落雷方位測 定装置 (DF) と, 複数の DF の落雷方位データから落雷 位置を計算する落雷点解析装置 (APA) で構成され, 広 範囲の落雷位置をリアルタイムで標定することが可能であ る。また，DFでは受信した信号が落雷によるものか否か を一定の波形判別基準に基づいて判別しているため, 判別 の信頼性が高いのが特徴である。

これまでに，新潟地域の雷性状について，地域や季節に よる違いを明らかにしたほか(2), 秋田を中心とする地域で も冬季雷の特徵が見られること尔を確認するなど, 数多く の成果を上げることができた。また，本システムによる観 測結果を, 年間雷雨日数 (IKL) マップなどと同様に送電
線耐雷設計基礎資料として活用する試みもなされ(4), 電力 設備雷対策に貢献するものとして期待されている。

しかし, 日本海側冬季雷については, 電磁界変化波形が 基準に適合しないものが多く捕捉率が十分でないこと(1), 中感度に設定した DF $3 \sim 4$ 台のネットワーク構成では広 い東北地域を高精度にカバーできないことがわかったた め, 信頼度の高い耐雷設計資料を得るにはこれらの改善が 必要であった。

著者らは，平成 2 年度から上記改善に取り組み, 平成 3 年度, 東北全域の観測が可能な実用システムを構築し運用 を開始した。本論文では，東北地域 LLP システムの性能 向上の方策と, 北緯 $36 \sim 42$ 度, 東経 136 142 度 30 分の 範囲で, 平成 3 年 8 月 2 日〜20日に観測されたデー夕を 用いて行ったシステムの評価結果について述べる。

\section{2. システム改善の内容}

システムの改善を行うにあたり，

（1）冬季雷の捕捉率を向上させること。

（2）東北全域で電流值換算 $10 \mathrm{kA}$ 以上の落雷を捕捉 可能であること。

（3）上記地域内で落雷の捕捉率・位置標定精度の低い 地域が存在しないこと。 


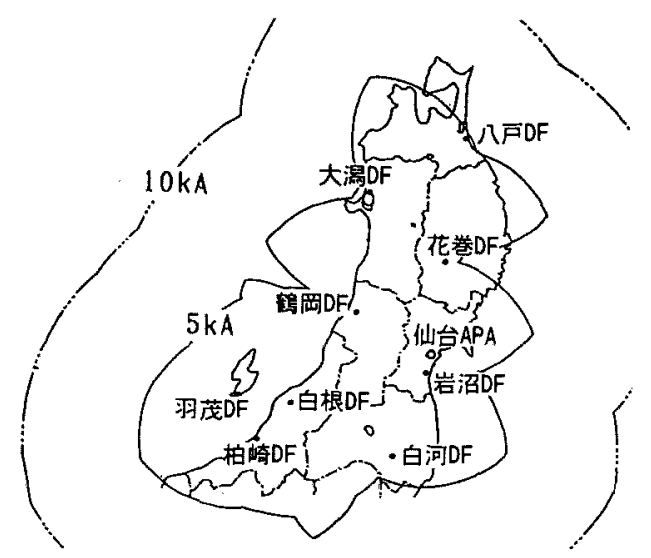

図 1 新システムの構成と小電流落雷捕捉可能範囲

Fig. 1. Configuration of new system and detection range of return stroke of small current.

を基本方針とした。具体的なシステム変更内容を以下に述 べる。

落雷の捕捉率は DF の配置・感度・ダイナミックレンジ， そして落雷のみを抽出するための波形判別基準で決まる。 そのなかでも影響の大きい波形判別基準沉ついては，波形 の最初のピークに対する逆極性側の振れの大きさ $b_{p}$ と, ピークから減少に転じてスレッショルドレベルを下回るま での時間 $t_{z}$ などがあり，新潟において広帯域で記録した 電磁界変化波形をもとに，落雷とみなす波形の $b_{p}$ の最大 值を $1.0, t_{z}$ の最小值を $6 \mu \mathrm{s}$ にするなどの変更により捕捉 率の改善を行った ${ }^{(5)}$ 。

感度については, 中感度のままスレッショルドレベルを 標準值の $50 \%$ とすることにより，ダイナミックレンジを 従来の 2 倍に拡大した。その結果，平均 DF 間隔を $65 \mathrm{~km}$ から $135 \mathrm{~km}$ に拡大することができた。

位置標定精度は, DF の設置環境・配置に左右される。 設置環境については, 東北地域は山岳地が多いものの平野 や盆地が散在しておう，河川や送電線などから離れた環境 雑音の少ない平地を探し出すことができた。また，配置に ついては, DF 3 台の増設と既設 DF の移設を行い， $9 \mathrm{DF}$ の配置の最適化を図った。これにより，隣接 DF 頂点と する三角形を正三角形に近いものにすることができた。

また，新潟・秋田システムの統合により，一つの落雷に 対して二つの標定データが存在する複雑さが解消されたほ か， $9 \mathrm{DF}$ の一元管理により信頼度の高いシステムとする ことができた。

新システムの構成と小電流落雷の捕捉可能範囲を図 1 に 示す。同図より，電流值 $10 \mathrm{kA}$ 以上の落雷を東北全域で 捕捉できることがわかる。

\section{3. 新システムにおける DF サイトエラー}

磁界による電磁波の到来方位測定における誤差の原因の うち，DF 設置条件によるものは，
（1）直交ループアンテナ設置方位の誤差

(2) アンテナ近傍の地形や障害物

の影響である。(1) は十分小さくすることが可能である が，(2)は DF 固有の系統的誤差として残り，一般には, （1），(2）を併せて方位測定におけるサイトエラーと呼 ぶ。DF ネットワークの標定精度向上にはこのサイトエラ 一の低減が重要である。

今回は, 初めに最適化標定点と DF の測定方位の差の分 布を調べた。ここで定義する最適化標定点とは，(1)式で 定義される $\chi^{2}$ を最小にする標定位置であり ${ }^{(6)}$, 時刻と極 性の一致した 3 台以上の DF のデータの中からオーバレン ジを除き, 信号強度の大きい順に 8 台までの DF からのデ 一夕を基に計算され，その結果を基準とした DF 測定方位 補正值, 最小化された $\chi^{2} /(n-2)$ とともに標定結果として 出力される。また, サイトエラーがランダム誤差であれば 十分低減されるが，それ以外の誤差は低減されずに残るた め，この処理を多数の標定データについて行うことによ り，各 DF 固有の系統的誤差を抽出することができる。し かし，最適化標定データには原データに含まれる䛊差の影 響が残るため，1回の解析で評価された補正值は小さめに 現れる。

$$
\chi^{2}=\sum_{j=1}^{N}\left[\frac{\left(\theta_{j}-\theta_{j}^{*}\right)^{2}}{\sigma_{\theta}^{2}}\right]
$$

$j: \mathrm{DF}$ 番号, $N: \mathrm{DF}$ 台数, $\theta_{j}$ : 測定方位, $\theta_{j}^{*}:$

最適化標定点の方位， $\sigma_{\theta}:$ 方位測定誤差の標準偏 差

一方，APA はあらかじめ設定した測定方位補正曲線に 従って, DF データを使った標定位置の再計算が可能であ る。そこで, DF の測定方位に対する補正值 $\Delta \theta$ を(2)式 で近似するため, 測定方位 10 度ごとの平均値から近似式 パラメータ $R 0, A_{k}, B_{k}$ を計算して測定方位補正曲線にフ イードバックし，それに従ってもとの DF データを再処理 するというプロセスを，測定方位補正曲線の補正幅が 0.2 度以下になるまで繰り返し, 最終的な補正曲線を求めた。

$$
\Delta \theta=R 0+\sum_{k=1}^{4}\left\{A_{k} \sin (k \theta)+B_{k} \cos (k \theta)\right\}
$$

DF 2 (柏崎), DF 9 (白河) の一次の測定方位補正値 の分布に最終的な補正曲線, 送電線事故点方位に対する補 正值を重社て図 2(a), (b)に示す。DF 2, DF 9 とも に系統的なサイトエラーが存在すること, 補正曲線が一次 の補正值に対応する点の密集した領域付近を通ること，送 電線事故点を基準とした補正值も補正曲線付近に分布する ことがわかる。(b)図におる゙いて，方位 180〜270 度の範囲 で点の分布と補正曲線にずれが見られるが，点は一次の補 正值に対応するため，最終的補正曲線とよく一致するとは 限らない。

図 3 (a),（b)には, 両 DF の最終的な補正值の個々の 点の, 補正曲線からのずれの分布の方位依存性を示す。方 位によるばらつきの度合の差, 補正しきれていない系統的 なサイトエラーはほとんど認められない。 

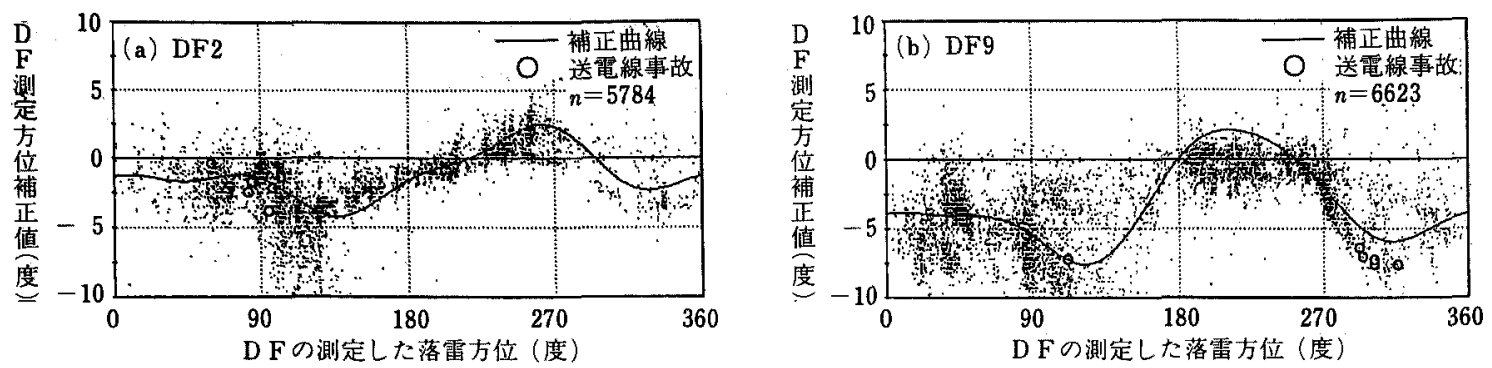

図 2 測定方位の一次の補正値の分布と最終的な補正曲線（DF 2, DF 9)

Fig. 2. Correction curve and distribution of primary value of site error correction at DF 2 and DF 9.
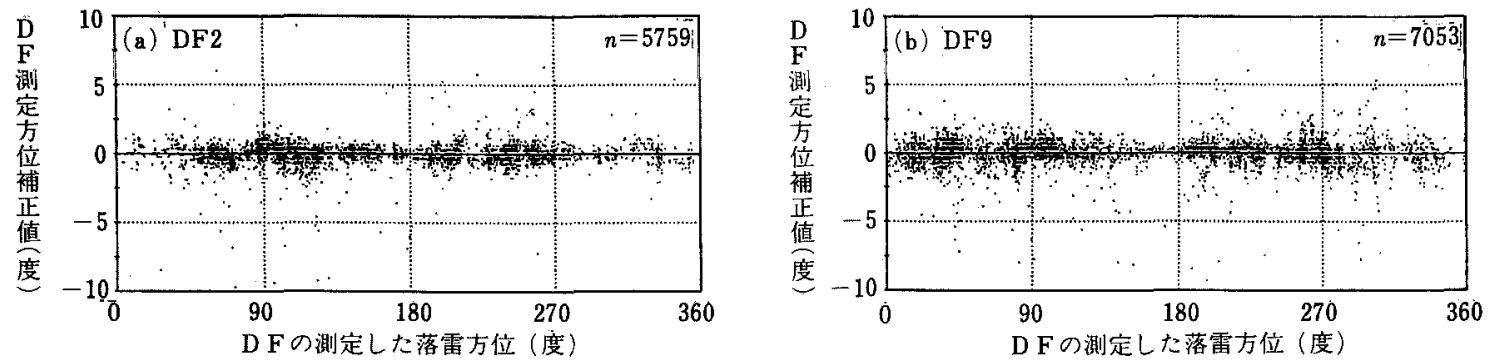

図 3 最終的な測定方位補正值の補正曲線からのずれの分布 (DF 2, DF 9)

Fig. 3. Distribution of difference between final value of site error correction at DF 2 and DF 9 .

\section{4. 最適化標定パラメータ $\chi^{2} /(n-2)$ による評価}

APA が最適化標定結果と一緒に出力する $\chi^{2} /(n-2) の$ 值は標定位置の最適化の程度, すなわち標定精度の信頼度 の指標と解釈できる。一方, 最適化処理は, DF 電子回路 の雑音などに起因するランダムエラーの低減を目的として いるが, それ以外の誤差が大きいと, 標定点の高精度化に 威力を発揮できない恐れがある。

サイトエラー補正前, 後の $\chi^{2} /(n-2)$ の分布を図 4 (a)，(b)に示す。な抢「SI済み」「SI 無し」はサイト エラ一補正の有無,「OPT 使用」・「OT 不使用」は最適 化処理の使用・不使用であることを示す。サイトエラー補 正に用いた補正曲線ば，9台の DF 各々について，前述の 手順を踏んで求めたものである。

図4（a)，(b)はともに $\chi^{2} /(n-2)$ の大きなデー夕ほど 頻度が低いが，(a)図では 200 を超えるデータが $3 \%$,

(b) 図では 40 を超えるデータが 1.5\%あり，これらのデ 一夕のために標準偏差が極端に大きくなっている。これら を除いたデー夕についての統計処理を(a)，(b)図中にそ れぞれ $<200,<40$ という欄に示した。 $\chi^{2} /(n-2)$ の飛び 抜けて大きなデー夕は，系統的な誤差・ランダム誤差以外 の原因，例えば DF 同期精度の限界などにより異なる雷撃 を同一雷とみなしたなどの原因により発生したものと推定 される。従って，システム出力の信頼度確保には，同期精 度の向上やパラメータのチェックによる異常データの排除 が必要である。

以上の考察をもとに，上記異常データによる解析への影 響を避けるため, 誤差は分布の中央值で評価することにす
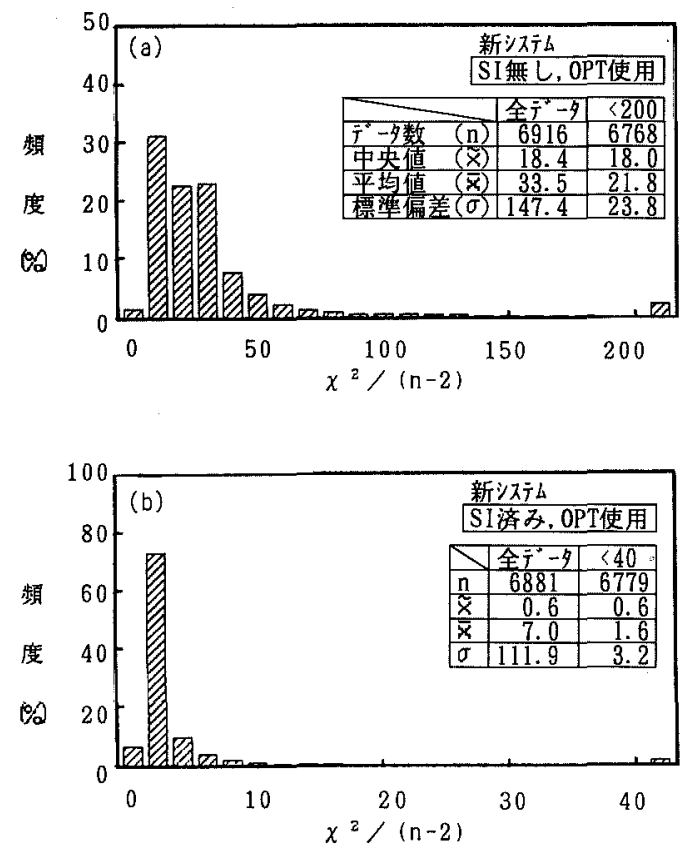

図 $4 \chi^{2} /(n-2)$ の分布

Fig. 4. Distribution of $\chi^{2} /(n-2)$.

る。中央值で評価すると, 図 4(a)，(b)の比較では， $\chi^{2} /$ $(n-2)$ はサイトエラー補正によってわずか $6 \%$ にまで減少 し，その効果が大きいことを確認した。

\section{5. システム構成の評価}

$\langle 5 \cdot 1\rangle$ 評価方法 APA は, 最適化標定点周囲の真 
の落雷点の存在確率を二次元正規分布と仮定し, DF 測定 方位の標準偏差 $1 \sigma_{\theta}$ に対応する誤差楕円の長径 $(\mathrm{km})$, 長 径/短径比，最小化された $\chi^{2} /(n-2)$ を出力する(7)。而灶 さしあたり 1 度と仮定されているが，これは安全側の数值 と考えられる(1)。この場合の誤差楕円は真の落雷点の存在 確率 $39 \%$ の領域を示し, 長径, 長径/短径比ともに, DF から落雷点までの距離や DF 測定方位の交差角に依存する ため，DF ネットワークの構成を反映する。この DF ネッ トワーク構成の変更により改善されたランダムな位置標定 愦差の分布などを, 観測されたデータを使用して解析した 結果を以下に述べる。

以後の図中,「新システム」は改善後のDF 9 台のネッ トワーク,「新潟システム」は改善前の新潟システムを想 定して新潟の $3 \mathrm{DF}$ のを動作させた模擬ネットワークの 解析結果を示す。

〈5・2〉 ネットワーク構成と誤差の分布 本システム 構築の目的が耐雷設計の基礎資料を得ることであるため, 陸上の精度向上が必要であり，評価も陸上に限定して行え ば十分である。しかし，DF のサイトエラーの評価は全方 位にわたって行う必要があることから, 海上の落雷データ も必要であり, システム改善の効果を明らかにするために も海上を含む広い範囲での解析を行ったものである。

誤差楕円の長径の新システムと新潟システムにおける頻 度分布を図 5 に示す。分布の中央值で比較すると, (a)図 は(b)図の $27 \%$ 格段に改善されている。つまり, 個々 のDF の落雷方位測定におけるランダムな誤差が同程度で あっても, ネットワーク構成を変えたことにより, 最適化
標定点の信頼度が大きく向上していることを意味する。

次に，長径／短径比の新システムと新潟システムにおけ る頻度分布を図 6 に示す。中央值で比較すると(a)図は (b)図の 45\%であり，誤差棈円がより円に近づいている ことがわかる。この結果から；新潟システムでは $\mathrm{DF}$ 間隔 が狭いために遠方の標定ほど長径／短径比が大きくなりや すく，その結果，長径が大きくなって精度が低下するた め，広域観測には適さない構成であることがわかる。

\section{〈5・3〉 新システムにおける誤差棈円の長径の分布}

緯度・経度とも $1 / 4$ 度のメッシュごとに誤差棈円の長径 の平均值を計算し， $4,8,16 \mathrm{~km}$ 未満の境界を等高線 表示したものを図 7 に示す。新潟を含む東北のほぼ全域で $4 \mathrm{~km}$ 未満であり, 当然ながらネットワークから遠くな るほど誤差が大きくなっている。しかし，南北に長いネッ トワークの内側のみならず, その両サイドについても高精 度の領域が広がっている。逆に, 南北両端ではネットワー ク近傍であるにもかかわらず，前述の両サイドほど高い精 度が得られていない。等高線の形状は, 平成 3 年 8 月〜 4 年 5 月の期間に得られた 14 万個以上のデータに基づいて 作成した分布 ${ }^{(8)}$ と同じであることを確認している。

以上，多数の DF のネットワーク化により DF 間隔増大 と同じ遠方落雷に対する標定精度向上効果が得られ，ネッ トワーク自体の拡大以上に高精度観測地域を拡大できるこ とを見いだした。

しかしこれまでの評価はすべて最適化標定に関するも のであるが，実際の落雷標定には DF 2 台のみによる標定 が含まれる。また，最適化パラメータなどではサイトエラ
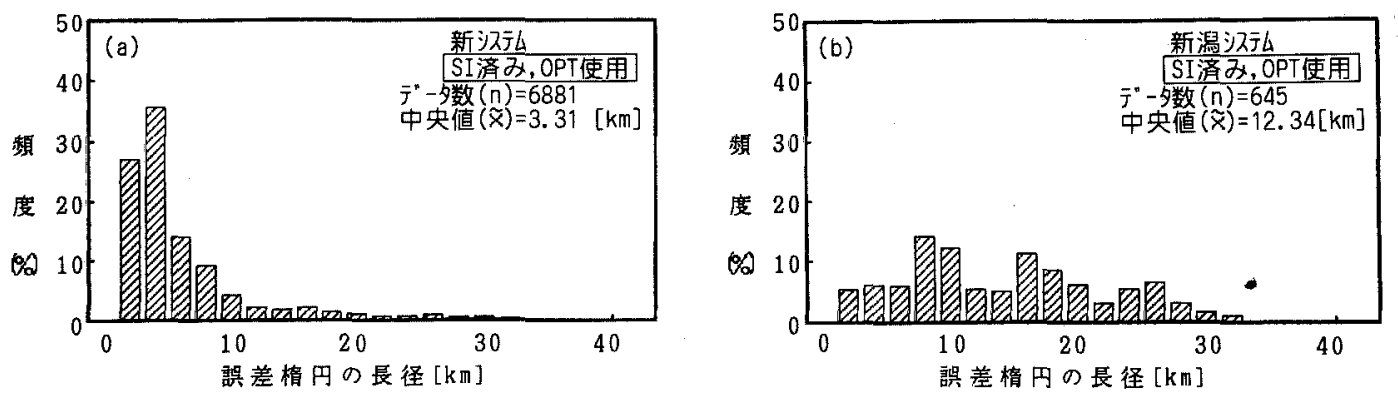

図 5 誤差楕円の長径の分布

Fig. 5. Distribution of semi-major axis length of error ellipse.
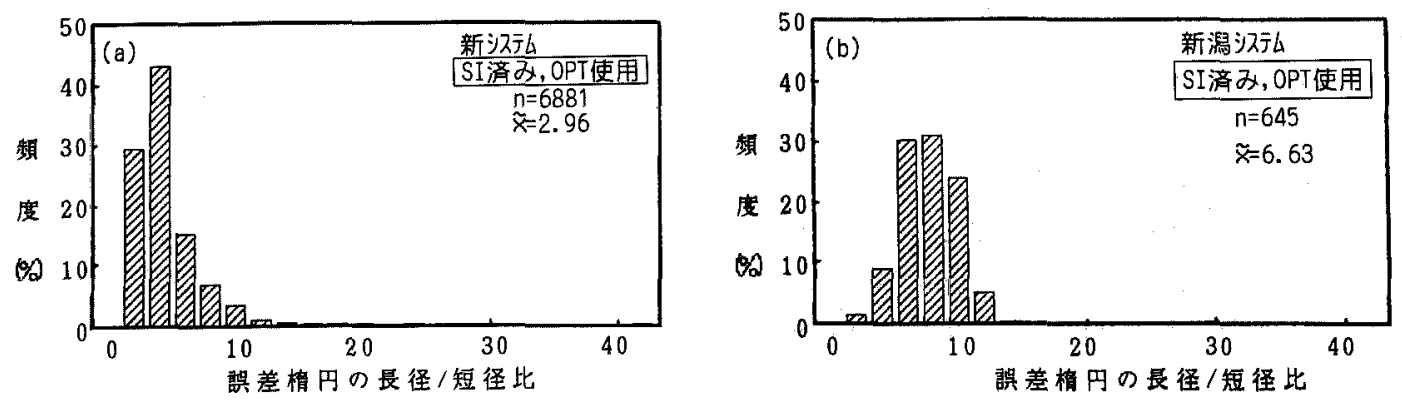

図 6 誤差棈円の長径/短径比の分布

Fig. 6. Distribution of ratio of major to minor axis of error ellipse. 


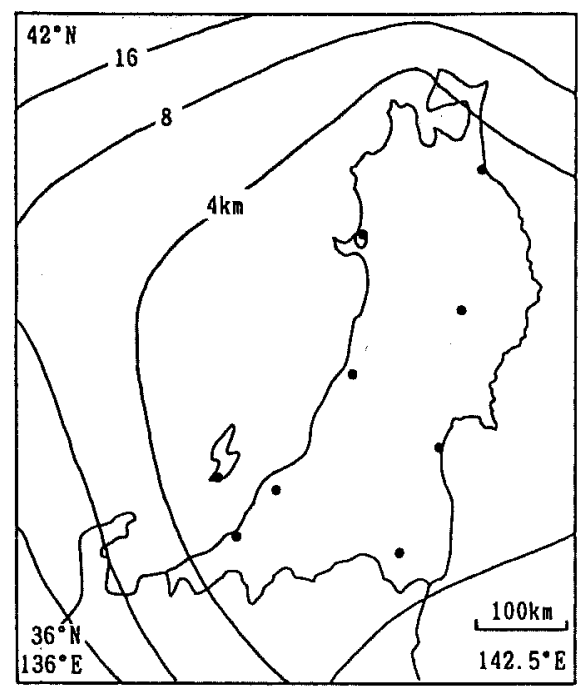

図 7 サイトエラー補正後の誤差棈円の 長径の中央值の分布

Fig. 7. Distribution of semi-major axis length (median value) of error ellipse after site error correction.

一補正の標定精度向上効果を評価できていない。そのた め，DF 2 台による標定を含めた総合的な解析が必要であ る。

\section{6. 誤差の大きさの総合的評価}

前章までの解析結果をふまえ, システムの位置標定精度 を総合的に評価するため, DF サイトエラー補正と最適化 処理の両方を適用した最も信頼度の高い標定結果を基準と して, 実測デー夕を基に構成の異なるシステムとの比較を 行った結果を述べる。

同じ DF データを基に異なるシステム条件で再計算する と, 同一の落雷について位置の異なる二つの標定点が得ら れる。これらの標定点間の距離を誤差距離と定義し, 種々 のシステム条件の下で得られたその分布を図 8 に示す。比 較対象のシステム条件は，(a)図に示すサイトエラー補正 前で最適化処理を適用した新システム，(b)図に示すサイ トエラー補正前で最適化処理も適用しない新システム, (c)図に示すサイトエラー補正後ではあるが最適化処理は 適用しない新システム，ならびに(d)図に示すサイトエラ 一補正後で最適化処理も適用した新潟システムの 4 ケース とし，観測対象範囲は全域とした。

新システムどうしを誤差距離の分布の中央值で比較する と, (a), (b)図の比較から, サイトエラ一補正前では最 適化処理により誤差距離が $58 \%$ まで低減するが，(b), (c)図の比較から, 最適化処理を行わない場合でもサイト エラー補正のみで 7\%まで低減することがわかる。

また，サイトエラー補正と最適化処理の両方を行った新 潟システムを新システムと比較すると（d)図に見られる ように誤差距離の大きな標定データが残っており, DF 3 台で間隔が小さい新潟システムを広い範囲で比較した場
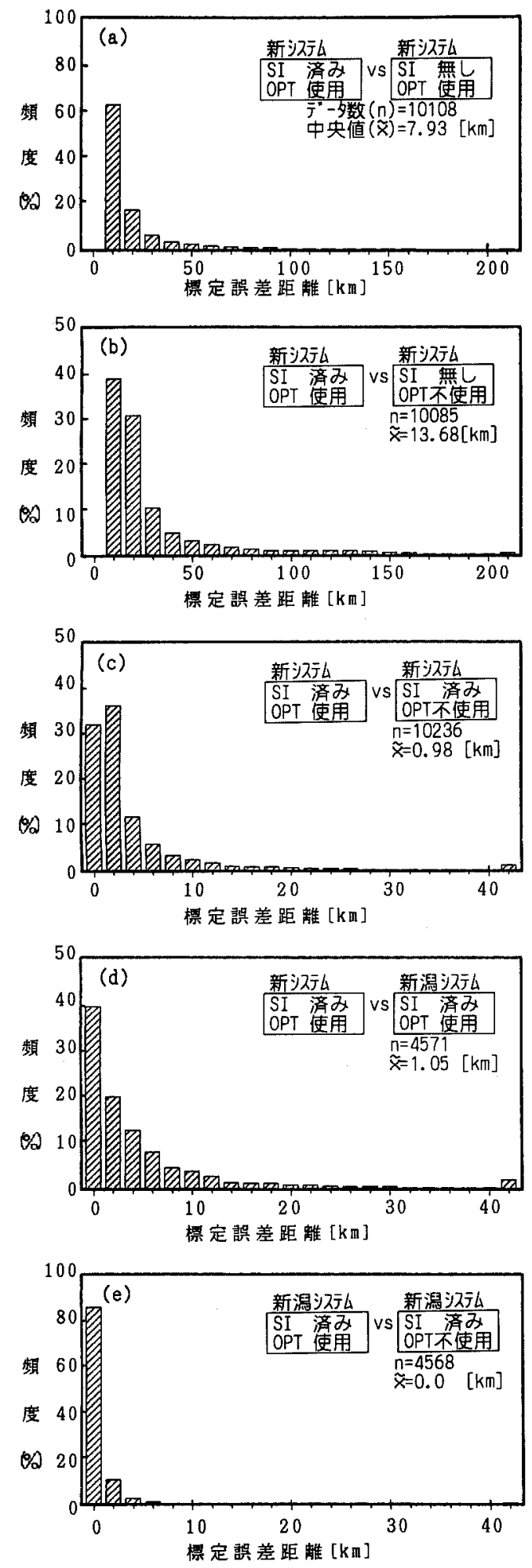

図 8 システム条件の違いによる標定誤差距離の分布

Fig. 8. Distribution of error in length between locations of the same lightning estimated by different systems.

合, サイトエラー補正と最適化処理を行っても, 精度向上 に限界があることがわかる。

また, サイトエラー補正後の新潟システムどうしで最適 化処理適用・不適用を比較すると，(e)図に示すように差 
表 1 最適化標定の割合のシステム条件 による違い

Table 1. Fraction of optimized data in lightning location for different systems.

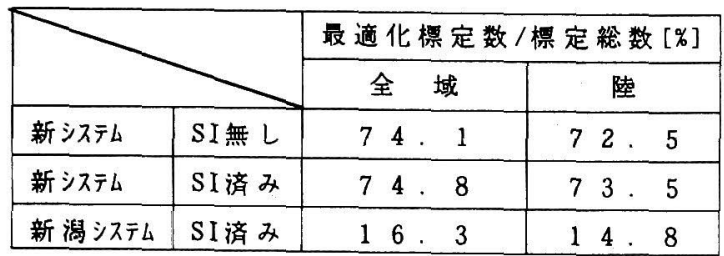

がほとんど認められない。これは, DF 3 台の新潟システ ムでは DF 2 台のみによる標定の割合が高いために, 最適 化処理が適用される率が低いことが原因であると推定され る。

標定総数に対する最適化標定数の割合のシステム条件に よる違いを表 1 に示す。

同表より, DF 9 台の新システムでは標定総数の $70 \%$ 以 上が最適化処理されるが，DF 3 台の新潟システムでは 20\%に満たないことがわかる。これは, 前章で図 7 (e)に ついて行った検討結果を支持するものであり，標定精度向 上のための最適化処理を活用するには, DF 4 台以上の構 成が望ましい。

以上のように，最適化処理は適用可能な標定データが限 られるのに対し, DF サイトエラー補正は全標定データに 適用可能で, その結果, 標定精度が向上するため, その効 果が最適化処理のみに比べて一般に大きいものと考えられ る。

\section{7.むすび}

東北全域を観測可能な落雷位置標定システム (LLP シ ステム)の高性能化について検討した。捕捉率については 波形判別基準の適正化により, 位置標定精度については DF のダイナミックレンジ，配置間隔の拡大により精度の 高い領域を効率的に拡大する一方, DF の適切な配置, サ イトエラーの補正, 最適化標定処理の効果的活用により, 向上させることができた。

また，観測結果を用いたシミュレーションにより，最適 化処理のみでも特にDF 4 台以上のネットワークでは位置 標定精度向上に威力を発揮するが，DFサイトエラー補正 が最も効果的であることを確認した。

今後は, ピーク電流值推定などにおける精度向上を図 り，信頼度の高い雷デー夕収集を目指す予定である。

最後に, デー夕解析に御協力いただいた(株)サンコーシ ヤ, LLP 社ならびに(株)シーブイエンジニアリングに感 謝の意を表します。

(平成 5 年 1 月 29 日受付)

\section{文献}

（1）北條, 他：「落雷に伴う電磁界変化波形の特性之評価法」, 電学 論 B, 108，165（昭 63-4）

(2) J.Hojo, et al.: "Seasonal Variation of Cloud-to-Ground Lightning Flash Characteristics in the Coastal Area of the
Sea of Japan”, J. Geophys. Res., 94, 13207 (1989)

（3）本間, 他：「秋田 LLSによる雷観測結果」, 電気学会放電・高電 圧合同研資, ED-89-93；HV-89-36 (平元)

（4）石井，他：「電磁界観测で得た雷パラメータによる送電線雷事 故率の検討」, 電学論 B, 111，535 (平 3-5)

（5）北條, 他：「LLP システムの落雷捕捉に関する実験的検討」, 平 3 電気学会 電力・エネルギー部門大会(II), 261

(6) W. L. Hiscox, et al. : "A Systematic Method for Identifying and Correcting 'Site Errors' in a Network of Magnetic Direction Finders", Int. Aerospace and Ground Conf. on Lightning and Static Electricity, Orlando, 7-1 (1984)

(7) LLP, Inc. : System Reference Manual Model 280 Series APA, June 1 (1990)

（8）本間，他：「東北地域 LLP システムの動作特性」，電気学会放 電・高電圧合同研資, ED-92-189；HV-92-75（平 4 ）

本 間 規 泰 (正員) 1957 年 5 月 1 日生。1983 年 3 月東北大

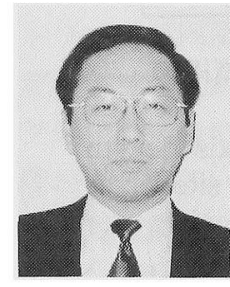
学大学院工学研究科電子工学専攻修士課程修了。 同年 4 月東北電力 (株) 入社。現在, 電力技術研 究所において, 主として, 雷に関する研究に従 事。

小室弘（正員） 1935 年 1 月 1 日生。1957 年 3 月富山大 学工学部電気工学科卒業。同年 4 月東北電力 (株) 入社。現在, 工務部付。

石 井勝 (正員) 1949 年 3 月 11 日生。1976 年 3 月東京

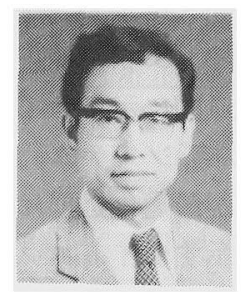
大学大学院工学系研究科博士課程修了。同年 4 月同大助教授, 生産技術研究所勤務, 1992 年 7 月同教授, 現在に至る。工学博士。主として, 系統絶縁, 自然雷, 高電圧現象の測定に関する 研究に従事。1988 年度日本大気電気学会学術研 究賞受賞。1989，90 年度電気学会東京支部評議 員。電気設備学会, 日本大気電気学会, 日本気 象学会, 静電気学会, IEEE Senior Member。

北 條 準 一 (正員) 1940 年 2 月 10 日生。1962 年千葉工業

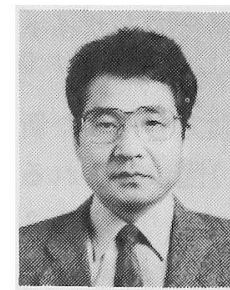
大学電気工学科卒業。同年 4 月東京大学生産技 術研究所勤務。現在, 同大学助手。工学博士。 主として, 雷に関する研究に従事。 